\title{
Pengaruh Pupuk Organik Hasil Fermentasi Biogas Kotoran Sapi Terhadap Pertumbuhan Dan Produksi Kacang Tanah (Arachis hypogaea L.)
}

\author{
Harli A. Karim ${ }^{1}$, Fitriani ${ }^{2}$, Nurhaya Kusmiah ${ }^{3}$, Nihlawati ${ }^{4}$ \\ 1,2,4 Program Studi Agroteknologi Fakultas Ilmu Pertanian Universitas Al Asyariah Mandar \\ ${ }^{3}$ Program Studi Agroteknologi Fakultas Ilmu Pertanian Universitas Al Asyariah Mandar \\ Email : harlipertanian@gmail.com
}

\begin{abstract}
Abstrak
Kacang tanah merupakan salah satu jenis tanaman penting di indonesia. Selain memiliki nilai gizi yang cukup tinggi, pemamfaatan kacang tanah sebagai buuk masak atau sebagai bahan baku berbagai industri makanan, minuman dan obatobatan. Salah satu penyebab rendahnya produkifitas kacang tanah adalah teknik pemupukan yang belum tepat. Pemupukan merupakan salah satu fakor yang mempengaruhi produktifitas tanaman kacang tanah. Salah satu teknologi alternatif yang di kembangkan adalah Biogas, pemanfaatan limbah organik hasil fermentasi biogas kotoran sapi dari hasil biogas sebagai pupuk justu lebih ramah terhadap lingkungan. Penelitian ini di laksanakan di Desa Taan Kecamatan Tapalang Kabupaten Mamuju. Yang dilaksanakan pada bulan Oktober 2018 sampai dengan bulan Desember 2018. Bertujuan untuk mengetahui pengaruh pupuk organik hasil fermentasi biogas kotoran sapi terhadap pertumbuhan dan hasil kacang tanah (Arachis hipogaea L). Penelitian ini menggunakan rancangan acak kelompok yang terdiri dari $0,0,5 \mathrm{~kg}, 1 \mathrm{~kg}, 1,5 \mathrm{~kg}, 2 \mathrm{~kg}$ biogas setiap perlakuan diulang sebanyak 3 kali terdapat 15 satuan petak percobaan, hasil pengamatan pemberian pupuk dengan dosis $2 \mathrm{~kg}$ menunjukan pengaruh sangat nyata terhadap pertumbuhan tinggi tanaman, waktu muncul bunga pertama, berat polong basah, berat polong kering, jumlah polong kering dan jumlah polong hampa yang berpengaruh baik dengan rata-rata terendah.
\end{abstract}

\section{Kata Kunci : pupuk organik, fermentasi biogas, sapi, kacang tanah}

\section{Pendahuluan}

Kacang tanah (Arachis hypogaea L.) merupakan salah satu jenis tanaman penting di Indonesia. Selain memiliki nilai gizi yang cukup tinggi, Kacang tanah juga memiliki nilai ekonomi yang tinggi. Pemanfaatan Kacang tanah sebagai bumbu masak atau sebagai bahan baku berbagaii industri makanan, minuman dan obatobatan membuat Kacang tanah semakin menarik untuk di usahakan. Prospek pengembangan kacang tanah sangat cerah karena permintaan konsumen di hari hari besar keagamaan dan swalayan tidak mampu untuk memenuhi permintaan pasar.

Pertambahan penduduk dan pesatnya perkembangan industrii makanan berbahan baku kacang tanah telah memicu peningkatan permintaan kacang tanah. Namun disisi lain, produksi dalam negeri tidak mampu memenuhi peningkatan yang terus meningkat, produksi kacang tanah justru mengalami penurunan. Badan Pusat Statistik dan Direktorat Jendral Pangan melaporkan produksi kacang tanah di tahun 2016 ke tahun 2017, dalam skala provinsi khususnya Sulawesi Barat mengalami penurunan dari 433 ton pada tahun 2016 turun menjadi 327 ton pada tahun 2017 sedangkan dalam skala nasional Indonesia menghasilkan 507.477 ton di tahun 2016 juga mengalami penurunan produksi menjadi 455.396 ton di 2017 (BPS, 2017). Sehingga upaya yang dilakukan untuk peningkatan produksi Kacang tanah dapat dilakukan dengan berbagai cara, antara lain memperluas areal panen, menekan senjang hasil, menekan kehilangan hasil dan meningkatkan produktivitas (Swastika 2013).

Untuk itu, diperlukan sesuatu bahan atau zat yang bukan hanya menyehatkan, tetapi juga ramah terhadap lingkungan. Antara lain adalah pupuk organik. Pupuk organik adalah pupuk yang sebagian besar atau seluruhnya terdiri atas bahan organik yang berasal dari tanaman atau hewan yang telah melalui proses penguraian dan fermentasi, dapat berbentuk padat atau cair (Achmad, 2011 ) dalam (Ajang Maruapay, 2015). Pemberian pupuk organik biasa dan kebanyakan di lakukan petani hanya melalui tanah, sehingga unsur hara yang di berikan di serap oleh akar tanaman, kemudian di transformasi menjadi bahan-bahan yang berguna bagi pertumbuhannya (Abdurahman dan Jumiati, 2007) dalam (Ajang Maruapey, 2015).

Salah satu teknologi alternatif yang dikembangkan adalah biogas. Pemanfaatan limbah organik kotoran sapi dari hasil biogas sebagai pupuk justru lebih ramah terhadap lingkungan. Selain itu, dapat memperbaiki sifat fisik, kimia dan biologi tanah, sehingga meskipun penggunaannya dalam jumlah besar tidak akan merusak tanah bahkan membantu kelestarian lahan pertanian yang berkelanjutan. Menurut (Risnawati, 2013) Kotoran sapi adalah bahan yang banyak digunakan untuk pupuk tanaman, namun penggunaan pupuk seperti ini proses penguraiannya agak lambat (Slow release) sehingga perlu dilakukan fermentasi lebih dahulu baru kemudaian dimanfaatkan sebagai pupuk organik bagi 
tanaman, Pemanfaatan biogas selain sebagai sumber energi penerangan dan sumber energi memasak, juga sebagai pupuk organik yang bahan baku biogas seperti lumpur dari kotoran sapi merupakan bahan organik yang mempunyai kandungan Nitrogen $(\mathrm{N})$ yang ada masih tetap bertahan dalam sisa bahan, yang akhirnya akan menjadi sumber $\mathrm{N}$ bagi pupuk organik.

Hasil penelitian yang dilakukan oleh (Reflianty,dkk 2012) dengan mengggunakan kompos sisa biogas pada tanaman kedelai di tanah ultisol dengan dosis sebanyak 20 Ton ha-1 memberikan hasil terbaik terhadap produksi kedelai. Menurutnya limbah biogas dari kotoran sapi sangat berperan dalam memperbaiki kesuburan tanah, meningkatkan daya serap air sehingga memberikan kondisi yang baik untuk perkembangan mikroorganisme dalam tanah. Sedangkan (Muhammad,dkk 2014) dalam hasil penelitiannya melaporkan bahwa penggunaan kompos biogas dengan dosis 9,5 ton/ha, mampu meningkatkan hasil terung $38,72 \%$ dengan hasil 2,13 ton/ha, dan efek residunya untuk musim tanam berikutnya, mampu memberikan hasil lebih tinggi yaitu sebesar 2,6 ton/ha.

Berdasarkan uraian tersebut, meskipun sudah banyak penelitian tentang pengaruh penggunaan pupuk organik dari kotoran ternak sapi terhadap pertumbuhan dan produksi Kacang tanah. Namun pemanfaatan limbah ternak sapi hasil biogas belum banyak dilakukan. Oleh karena itu, penelitian ini dilakukan dengan tujuan untuk mengetahui pertumbuhan dan produksi Kacang tanah jika diaplikasikan dengan limbah hasil biogas kotoran sapi berbagai tingkat dosis.

\section{Bahan dan Metode}

Penelitian ini dilaksanakan di Desa Taan, Kecamatan Tapalang, Kabupaten Mamuju, Provinsi Sulawesi Barat berlangsung pada bulan September 2018 sampai Desember 2018. Bahan yang digunakan dalam penelitian ini adalah benih kacang tanah varietas Kancil, Pupuk hasil Fermentasi biogas kotoran sapi dalam bentuk padat, alat yang digunakan adalah cangkul, tugal, timbangan, penggaris, meteran, sprayer, alat tulis, kamera, plastik dan label.

Penelitian ini menggunakan Rancangan Acak Kelompok atau RAK, terdiri dari satu faktor yang terdiri dari 5 perlakuan yaitu $\mathrm{B} 0=$ kontrol, $\mathrm{B} 1=0,5 \mathrm{~kg} \mathrm{~m} / 2$, $\mathrm{B} 2=1 \mathrm{~kg} / \mathrm{m} 2, \mathrm{~B} 3=1,5 \mathrm{~kg} / \mathrm{m} 2, \mathrm{~B} 4=2 \mathrm{~kg} / \mathrm{m} 2$. Setiap perlakuan di ulang sebanyak 3 kali sehingga seluruhnya terdapat 15 satuan petak penelitian. Setiap petak penelitian terdapat 16 tanaman sehingga keseluruhannya adalah 240 tanaman, setiap petak di ambil 4 tanaman sebagai tanaman sampel.

Hasil penelitian ini selanjutnya dianalisis dengan menggunakan analisis sidik ragam sesuai dengan rancangan yang di gunakan, apabila berpengaruh nyata, maka di lanjutkan dengan Uji Beda Nyata Terkecil (BNT)

\section{Hasil dan Pembahasan}

Hasil analisis menunjukan bahwa pemberian limbah biogas kotoran sapi dengan berbagai dosis berpengaruh nyata terhadap tinggi tanaman dengan nilai rata-rata tertinggi di setiap pengamatan $48,75 \mathrm{~cm} 8 \mathrm{MST}$ dan yang paling terendah $40,83 \mathrm{~cm} 8$ MST pada parameter tinggi tanaman.

Tabel 1. Rata-rata tinggi tanaman kacang tanah pada berbagai dosis pupuk organik hasil fermentasi biogas kotoran sapi.

\begin{tabular}{lcccc}
\hline PERLAKUAN & 2 & 4 & 6 & 8 \\
& MST & MST & MST & MST \\
\hline B0 $\left(0 \mathrm{~kg} / \mathrm{m}^{2}\right)$ & $8,17^{\mathrm{a}}$ & $18,25^{\mathrm{a}}$ & $34,67^{\mathrm{a}}$ & $40,83^{\mathrm{a}}$ \\
B1 $\left(0,5 \mathrm{~kg} / \mathrm{m}^{2}\right)$ & $9,50^{\mathrm{b}}$ & $20,58^{\mathrm{b}}$ & $38,50^{\mathrm{b}}$ & $42,58^{\mathrm{b}}$ \\
B2 $\left(1 \mathrm{~kg} / \mathrm{m}^{2}\right)$ & $11,00^{\mathrm{c}}$ & $22,25^{\mathrm{c}}$ & $40,25^{\mathrm{c}}$ & $44,17^{\mathrm{c}}$ \\
B3 $\left(1,5 \mathrm{~kg} / \mathrm{m}^{2}\right)$ & $11,75^{\mathrm{d}}$ & $23,33^{\mathrm{d}}$ & $41,33^{\mathrm{d}}$ & $45,33^{\mathrm{d}}$ \\
B4 $\left(2 \mathrm{~kg} / \mathrm{m}^{2}\right)$ & $13,50^{\mathrm{e}}$ & $24,50^{\mathrm{e}}$ & $44,08^{\mathrm{e}}$ & $48,75^{\mathrm{e}}$ \\
\hline
\end{tabular}

Keterangan: Angka yg diikuti oleh huruf yang berbeda berarti berbeda nyata pada BNT taraf $\alpha 0,01$

Berdasarkan BNT taraf $\alpha 0,01$ yang disajikan pada tabel 1 menunjukkan bahwa pupuk organik hasil fermentasi biogas kotoran sapi dengan dosis $2 \mathrm{~kg} / \mathrm{m} 2$ (B4), memberikan hasil terbaik dan berbeda sangat nyata dibanding perlakuan dosis yang lainnya dengan nilai rata-rata tertinggi di setiap pengamatan $48,75 \mathrm{~cm} 8 \mathrm{MST}$ dan yang paling terendah $40,83 \mathrm{~cm}$ MST.

Data pada tabel 1 memperlihatkan bahwa peningkatan dosis memberikan pertumbuhan tanaman semakin tinggi. Pemberian dengan dosis $2 \mathrm{~kg}$ limbah biogas kotoran sapi per petak memberikan pengaruh meningkatkan tinggi tanaman secara nyata. Hal ini di duga karena tanaman melakukan pertumbuhan secara optimal.di bandingkan dengan dosis yang lebih rendah, hal yang sama juga di kemukakan oleh Lingga dan Marsono (2006) dalam Muhammad dkk (2014) bahwa ketersediaan unsur $\mathrm{N}, \mathrm{P}$ dan $\mathrm{K}$ bagi tanaman secara umum berfungsi untuk memacu pertumbuhan dan produksi tanaman. Sedangkan Reflianti, dkk (2012) mengemukakan bahwa perlakuan pupuk kandang limbah biogas kotoran sapi mampu menyediakan sejumlah unsur hara makro dan mikro yang dibutuhkan langsung oleh tanaman. 
Tabel 2. Rata-rata waktu muncul bunga pertama kacang tanah pada berbagai dosis pupuk organik hasil fermentasi biogas kotoran sapi.

\begin{tabular}{lcc}
\hline PERLAKUAN & RATA-RATA & $\begin{array}{c}\text { NP BNT } \\
\text { a0,01 }\end{array}$ \\
\hline B0 $\left(0 \mathrm{~kg} / \mathrm{m}^{2}\right)$ & $26,75^{\mathrm{a}}$ & 0,24 \\
B1 $\left(0,5 \mathrm{~kg} / \mathrm{m}^{2}\right)$ & $26,33^{\mathrm{b}}$ & \\
B2 $\left(1, \mathrm{~kg} / \mathrm{m}^{2}\right)$ & $25,92^{\mathrm{c}}$ & \\
B3 $\left(1,5 \mathrm{~kg} / \mathrm{m}^{2}\right)$ & $25,58^{\mathrm{d}}$ & \\
B4 $\left(2 \mathrm{~kg} / \mathrm{m}^{2}\right)$ & $25,25^{\mathrm{e}}$ & \\
\hline
\end{tabular}

$\mathrm{Kk}=0,59 \%$

Keterangan: Angka yg diikuti oleh huruf yang berbeda berarti berbeda nyata pada BNT taraf $\alpha 0,01$

Berdasarkan BNT taraf $\alpha 0,01$ yang disajikan pada tabel 2 menunjukkan bahwa pupuk organik hasil permentasi biogas kotoran sapi dengan dosis 2 $\mathrm{kg} / \mathrm{m} 2$ (B4), memberikan hasil terbaik dan berbeda sangat pembungaan dan pemasakan buah. Sedangkan unsur K berperan penting dalam proses fotosintesis, membantu pembentukan karbohidrat dan meningkatkan kualitas hasil berupa bunga dan buah, rasa dan warnanya.

Hal senada juga di kemukakan oleh Sutedjo (2008) dalam Ajang Maruapay 2015), bahwa pada saat pembentukan kuncup bunga, tanaman tanaman banyak menyerap zat makanan atau unsur hara nitrogen $(\mathrm{N})$ atau fospor $(\mathrm{P})$ yang di berikan melalui pemupukan sehingga dapat mempercepat proses pembunggan dan pemasakan buah dan biji. Hal ini juga sesuai dengan pendapat Lakitan (2010) yang mengatakan bahwa meningkatnya pertumbuhan tanaman maka akan berdampak pula pada percepatan proses pembungaan sehingga jangka waktu berbunga lebih pendek, Muhammad,dkk (2014) yang menyatakan bahwa pupuk organik dari hasil biogas kotoran sapi yang telah hilang gasnya yang dengan cepat terdekomposisi sehingga mampu memberikan zat makanan yang esensial bagi tanaman dalam memacu pertumbuhan tanaman.

Tabel 3. Rata-rata pertumbuhan generatif kacang tanah pada berbagai dosis pupuk organik hasil fermentasi biogas kotoran sapi

\begin{tabular}{cccccc}
\hline $\begin{array}{c}\text { Dosis Pupuk } \\
\text { Organik Biogas } \\
\left(\mathrm{kg} / \mathrm{m}^{2}\right)\end{array}$ & $\begin{array}{c}\text { Berat } \\
\text { Polong } \\
\text { Basah } \\
(\mathrm{g}) * *\end{array}$ & $\begin{array}{c}\text { Berat Polong } \\
\text { Kering } \\
(\mathrm{g}) * *\end{array}$ & $\begin{array}{c}\text { Jumlah } \\
\text { Polong } \\
\text { Berisi } \\
* *\end{array}$ & $\begin{array}{c}\text { Jumlah } \\
\text { Polong } \\
\text { Hampa } \\
\text { tn }\end{array}$ & $\begin{array}{c}\text { Berat Biji } \\
(\mathrm{g}) \\
* *\end{array}$ \\
\hline 0 & $9.25 \mathrm{a}$ & $5.42 \mathrm{a}$ & $7.33^{\mathrm{a}}$ & 1.00 & $4.50 \mathrm{a}$ \\
0.5 & $10.08 \mathrm{~b}$ & $6.25 \mathrm{~b}$ & $7.67^{\mathrm{a}}$ & 1.00 & $4.83 \mathrm{~b}$ \\
1.0 & $10.92 \mathrm{c}$ & $6.2 \mathrm{c}$ & $8.58^{\mathrm{b}}$ & 1.00 & $5.75 \mathrm{c}$ \\
1.5 & $11.42 \mathrm{~d}$ & $8.17 \mathrm{~d}$ & $9.23^{\mathrm{c}}$ & 1.30 & $6.67 \mathrm{~d}$ \\
2.0 & $13.33 \mathrm{e}$ & $9.83 \mathrm{e}$ & $11.42^{\mathrm{d}}$ & 0.60 & $8.42 \mathrm{e}$ \\
\hline KK $(\%)$ & 2.25 & 3.99 & 4.46 & 6.33 & 2,00 \\
\hline BNT $(1 \%)$ & 0.39 & 0.46 & 0.62 & - \\
\hline Keterangan: Angka yg diikuti oleh huruf yang berbeda berarti berbeda nyata pada BNT taraf $\alpha 0,01$ & \\
$* *$ Sangat Nyata, tn = Tidak Nyata
\end{tabular}

nyata terhadap waktu muncul bunga pertama dibanding perlakuan dosis yang lainnyadengan nilai rata-rata 25,25 hst dan nilai terendah 26,75 hst.

Hasil analisis menunjukan bahwa pemberian limbah biogas kotoran sapi dengan berbagai dosis berpengaruh nyata terhadap umur berbunga tanaman kacang tanah. Data pada tabel 3 memperlihatkan bahwa peningkatan dosis mempercepat pembungaan dengan dosis $2 \mathrm{~kg} / \mathrm{m} 2$ memberikan hasil terbaik dan berbeda sangat nyata terhadap waktu muncul bunga pertama dibanding perlakuan dosis yang lainnya dengan nilai rata-rata 25,25 hst dan nilai yang terendah 26,75 hst. Pemberian dosis $2 \mathrm{~kg}$ per petak di duga dapat menyediakan unsur hara makro dan mikro memenuhi kebutuhan unsur hara serta mampu mensuplai unsur hara yang di serap oleh tanaman kacang tanah sehingga mendorong perkembangan tanaman terutama dalam pembentukan cabang yang dapat menghasilkan bunga menjadi buah. Sebagai mana di katakan oleh Setyamidjaya (2006) dalam Ajang Maruapey 2017), bahwa unsur $\mathrm{P}$ berperan penting untuk mempercepat
Berdasarkan BNT taraf $\alpha 0,01$ yang disajikan pada tabel 3 menunjukkan bahwa pupuk organik hasil fermentasi biogas kotoran sapi dengan dosis $2 \mathrm{~kg} / \mathrm{m} 2$ (B4), Memberikan hasil terbaik dan berbeda sangat nyata terhadap berat polong basah dibanding perlakuan dosis yang lainnya dengan nilai rata-rata 13,33 polong dan nilai terendah 9,55 polong.

Hasil analisis menunjukan bahwa pemberian limbah biogas kotoran sapi dengan berbagai dosis berpengaruh nyata terhadap berat polong basah. Memberikan hasil terbaik dan berbeda sangat nyata terhadap berat polong basah dibanding perlakuan dosis yang lainnya dengan nilai rata-rata 13,33 polong dan nilai terendah 9,55 polong. Data pada tabel 3 memperlihatkan bahwa peningkatkan dosis pupuk $2 \mathrm{~kg}$ per petak di duga memberikan pengaruh secara nyata terhadap berat polong basah, pemberian pupuk organik limbah biogas kotoran sapi sebanyak $2 \mathrm{~kg}$ per petak menyebabkan ketersediaan nutrisi yang lebih banyak sehingga dapat meningkatkan pertumbuhan dan produksi 
tanaman kacang tanah. Hal ini sesuai pendapat Lingga dan Marsono (2006) dalam Ajang Maruapay (2017), bahwa pemberian bahan organik selain dapat memperbaiki sifat kimia tanah juga dapat memperbaiki sifat fisik dan sifat biologis, maka tanaman dapat tumbuh dan dan berfroduksi dengan baik.Sedangkan Hasil penelitian Muhammad,dkk (2014) mengemukakan bahwa peranan pupuk organik hasil olahan limbah biogas terhadap sifat fisik tanah adalah menyediakaan sejumlah unsur hara makro dan mikro bagi kepentingan pertumbuhan dan produksi maksimum baik dari segi kualitas .

Berdasarkan BNT taraf $\alpha 0,01$ yang disajikan pada tabel 3 menunjukkan bahwa pupuk organik hasil fermentasi biogas kotoran sapi dengan dosis 2 $\mathrm{kg} / \mathrm{m} 2$ (B4), Memberikan hasil terbaik dan berbeda sangat nyata terhadap berat polong kering dibanding perlakuan dosis yang lainnya dengan nilai rata-rata9,83 polong dan nilai terendah 5,42 polong.

Hasil analisis menunjukan bahwa pemberian limbah biogas kotoran sapi berbagai dosis berpengaruh nyata terhadap berat polong kering Memberikan hasil terbaik dan berbeda sangat nyata terhadap berat polong basah dibanding perlakuan dosis yang lainnya dengan nilai rata-rata 9,83 polong dan nilai yang terendah 5,42 polong. Data pada tabel 4 memperlihatkan bahwa peningkatan dosis pupuk $2 \mathrm{~kg}$ per petak di duga memberikan pengaruh secara nyata di bandingkan dengan pemberian dosis yang lebih rendah. Hal ini sesuai dengan Gibson dan Tarore (2013) dalam Ajang Maruapey (2015), unsur hara makro yang ada pada pupuk biogas dari kotoran sapi sangat penting bagi tanaman. Di samping menghasilakn unsur hara makro,pupuk biogas juga menghasilkan sejumlah unsur hara mikro, seperti Fe, Zn, jadi dapat di katakan bahwa, pupuk kandang ini dapat di anggap sebagai pupuk alternatif untuk mempertahankan produksi tanaman secara maksimal dengan tetap menjaga keaman dan kelestarian produk organik tanpa merubah rekayasa genetik sehingga akrab terhadap lingkungan.

Berdasarkan BNT taraf $\alpha 0,01$ yang disajikan pada tabel 3 menunjukkan bahwa pupuk organik hasil fermentasi biogas kotoran sapi dengan dosis 2 $\mathrm{kg} / \mathrm{m} 2$ (B4), memberikan hasil terbaik dan berbeda sangat nyata terhadap jumlah polong berisi dibanding perlakuan dosis yang lainnya dengan nilai rata-rata 11,42 polong dan nilai terendah 7,33

Hasil analisis menunjukan bahwa pemberian limbah biogas kotoran sapi berbagai dosis berpengaruh nyata terhadap jumlah polong berisi Memberikan hasil terbaik dan berbeda sangat nyata terhadap berat polong basah dibanding perlakuan dosis yang lainnya dengan nilai rata-rata 11,42 polong dan nilai terendah 7,33 polong. Data pada tabel 5 memperlihatkan bahwa peningkatan dosis memberikan pertambahan jumlah polong berisi pemberian dosis pupuk $2 \mathrm{~kg}$ limbah biogas kotoran sapi perpetak di duga lebih meningkatkan jumlah polong berisi secara nyata di bandingkan dengan pemberian dosis yang lebih rendah. Demikian halnya Winarto (2010) dalam Ajang Maruapay (2017) yang menegaskan bahwa fungsi dari pupuk organik hasil olahan biogas untuk memperbaiki sifat fisik kimia dan biologis tanah, meningkatkan produksi tanaman dan menjaga kestabilan produksi, memfermentasi bahan organik tanah dan mempercepat dekomposisi serta menghasilakan kualitas dan kuantitas hasil tanaman.

Sedangkan Muhammad,dkk (2014), bahwa limbah biogas yang dijadikan sebagi pupuk selain mengandung unsur hara makro juga mengandung sejumlah unsur tertentu seperti protein, selulose, sehingga unsur-unsur tersebut berpengaruh terhadap jumlah polong besar kecilnya ukuran buah menjadi baro meter dalam menghasilkan panjang pendeknya ukuran buah.

Hasil analisis menunjukan bahwa pemberian limbah biogas kotoran sapi berbagai dosis terhadap jumlah polong hampa pada data diagram batang berpengaruh baik dengan dosis pupuk $2 \mathrm{~kg}$ per petak menunjukkan bahwa pupuk organik hasil fermentasi biogas kotoran sapi dengan dosis $2 \mathrm{~kg} / \mathrm{m} 2$ (B4), di duga memberikan rata-rata tertinggi di bandingkan dengan pemberian dosis yang lebih rendah yaitu 0,17 polong dan yang terendah 0,33 . Tidak semua polong dapat terisi penuh pada setiap perlakuan. Hal ini antara lain di sebabkan oleh ketersediaan hara di dalam tanah. Untuk pembentukan biji dan kesempurnaan biji di pengaruhi oleh unsur (P) Hakim dalam Tommy D. Sondah,dkk (2012). Unsur (P) yang berfungsi membantu respirasi dan juga proses fotosintesis pada tanaman, pembentukan bibit tanaman dan juga pembentukan buah, merangsang perkembangan akar tanaman sehingga tanaman lebih tahan terhadap adanya kekeringan dan mempercepat waktu panen Ginaini (2017)

Berdasarkan BNT taraf $\alpha 0,01$ yang disajikan pada tabel 3 menunjukkan bahwa pupuk organik hasil Fermentasi biogas kotoran sapi dengan dosis 2 $\mathrm{kg} / \mathrm{m} 2$ (B4), memberikan hasil terbaik dan berbeda sangat nyata terhadap berat biji dibanding perlakuan dosis yang lainnya dengan nilai rata-rata 8,42 gr dan yang terendah 4,50 gr.

Hasil analisis menunjukan bahwa pemberian limbah biogas sapi berbagai dosis berpengaruh nyata Memberikan hasil terbaik dan berbeda sangat nyata terhadap berat biji (gr) dibanding perlakuan dosis yang lainnya dengan nilai rata-rata 8,42 polong. Data pada tabel 3 memperlihatkan bahwa peningkatan dosis pupuk $2 \mathrm{~kg}$ limbah biogas sapi per petak di duga lebih meningkatkan pertambahan berat biji. Pertumbuhan dan perkembangan dari mulai berkecambah samapai kemudian di panen.Tanaman membutuhakan unsur hara tidak tersedianya unsur hara bagi tanaman akan menyebabkan pertumbuhan terganggu sehingga menurunnya produktifitas dan hasil tanaman. Menurunnya hasil tanaman juga di sebabkan oleh faktor tanah, jika tanah tidak subur tentu membuat tanaman tumbuh kurang optimal sehingga perlu penambahan organik penyubur tanah. Limbah biogas dari kotoran sapi memiliki peranan yang cukup besar terhadap perbaiakan sifat fisik, kimia, dan biologi tanah sehingga membuat tanaman dapat tumbuh subur dan menghasilakan produksi buah tanaman kacang tanah. Hal ini sesuai pendapat Muhammad,dkk (2014) mengemukakan bahwa 
pemberian bahan organik selain dapat memperbaiki sifat kimia tanah, juga dapat memperbaiki sifat fisik tanah adalah menyediakan sejumlah unsur hara makro dan mikro bagi kepentingan pertumbuhan dan produksi yang maksimum baik dari segi kualitas maupun kuantitas.Maka tanaman dapat tumbuh dan berproduksi dengan baik.

\section{Kesimpulan}

Berdasarkan hasil penelitian yang telah di lakukan, maka dapat di simpulkan sebagai berikut :

1. Pemberian pupuk organik hasil fermentasi biogas kotoran sapi pada dosis yang berbeda memberikan pengaruh yang nyata terhadap tinggi tanaman $(\mathrm{cm})$, waktu muncul bunga pertama (hari), berat polong basah (polong), berat polong kering (polong), jumlah polong berisi (polong), dan jumlah polong hampa pengaruhnya tidak nyata

2. Tanaman kacang tanah yang di berikan pupuk organik fermentasi biogas kotoran sapi dengan dosis $2 \mathrm{~kg} / \mathrm{m} 2$ memberikan hasil terbaik dan berbeda sangat nyata.

\section{Daftar Pustaka}

Ajang Maruapey, 2015 pengaruh pupuk organik limbah biogas kotoran sapi terhadap pertumbuhan dan produksi tanaman jangung. Jurnal Agroforestri ISSN : 1907-7556

Ajang Maruapey . 2017 Pengaruh Pupuk Organik Limbah Biogas Kotoran Sapi TerhadapPertumbuhan dan Produksi Tanaman Cabai Merah Keriting(Capsicum annum var. Longum). Jurnal Agrologia, 6, 93-100.

Badan Pusat Statistik dan Direktorat Jendral Pangan (2017).Produktivitas

Kacang Tanah.http://www.pertanian.go.id/appages/mod/datatp.

Bpp, $2018 \quad$ varietas kancil. http://www.litbang.pertanian.go.id/varietas/57/

Chandra Afrian, 2017produksi biogas dari campuran kotoran sapi dengan rumput gajah (pennisetum purpureum), universitas lampung, 2017

Ginaini, 2017. Manfaat Kotoran Sapihttps://manfaat.co.id/manfaat-kotoransapi[25/04/2018]
KrisnaIndra,2015,Klasifikasi dan Morfologi Kacang Tanah.

http://meteripengetahuanumum.blogspot.sg/201

6/10/klasifikasi-dan-morfologikacangtanah.html?m=1

Krisnakai 2017. Syarat tumbuh kacang tanahhttps://bukuteori.com/2017/08/26/syarattumbuh-kacang-tanah.

Lakitan, B. 2010. Fisiologi pertumbuhan dan perkembangan tanaman. Raja grapindo persada, Jakarta

Mashudi, 2007, Bercocok Tanam Kacang Tanah dan Manfaatnya, jakarta: Azka mulia media.

Muhammad,S. Abdul, R. dan J. Noor. 2014. Pengaruh jenis dan dosis pupuk organic kompos olahan Biogas terhadap pertumbuhan dan Hasil Tanaman Terung (Solamun melongena L.) Varietas Mustang F-1 Jurnal AGRIFOR Volume 12 (1): 1412-6885

Reflianty,Gindo.T, dan Hendriansyah, 2012.Pengaruh Pemberian Kompos Sisa Biogas Kotoran Sapi Terhadap Perbaikan Beberapa Sifat Fisik Ultisol dan Hasil Kedelai (Glycine max (L.)Merill). Jurnal Hidrolitan. Vol. 2:3:103-114, 2011 ISSN 2086-4825103

Risnawati,M.2013.ResponPertumbuhan dan Hasil Tanaman Caisim (Brassica Rapa L.) Akibat Pemberian Pupuk Kotoran Sapi Olahan Biogas di Kelurahan Dulomo Utara Kecamatan Kota Utara Kecamatan Kota Utara Kota Gorontalo.http://repository.ing.ac.id/skripsi/tahu n/2013. [24/04/2018]

Swastika,2013Ekonomi Kacang Tanah di Indonesis, Bogor.Balitkabi.litbang.pertanian.go.id

Tommy D. Sondakh, Djuhardi N. Joruh, A. G. Tulugen, D.M.F.Sumampou, Lita B. Kapugu, Rini Mamarimbing. 2012 hasil kacang tanah (Arachis hypogaea L ) pada berbagai jenis pupuk organik Eugenia volume 18. No 1 april 2012

Wahyuni, S. 2015. Panduan Praktis Biogas. Penebar Swadaya. Jakarta Timur.116 